\title{
Forskningsbiblioteket i nye læreprocesser
}

\author{
Claus Rosenstand \\ It-vest leder, ph. d. \\ c/o Institut for Kommunikation \\ It-vest, c/o Aalborg Universitet \\ clausr@it-vest.dk \\ www.it-vest.dk, www.hum.aau.dk
}

\section{Maj Rosenstand}

Publikumschef, cand.mag.

Aalborg Universitetsbibliotek

Aalborg Universitet

mr@aub.aau.dk

www.aub.aau.dk

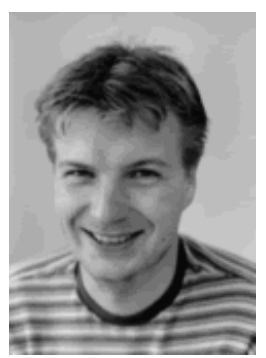

\section{Bo Hvass Pedersen}

Udviklingskonsulent, bibliotekar

Aalborg Universitetsbibliotek

Aalborg Universitet

bhp@aub.aau.dk

www.aub.aau.dk

\section{Niels-Henrik Gylstorff}

Overbibliotekar, cand.scient. MPH

Aalborg Universitetsbibliotek

Aalborg Universitet

nhg@aub.aau.dk

www.aub.aau.dk
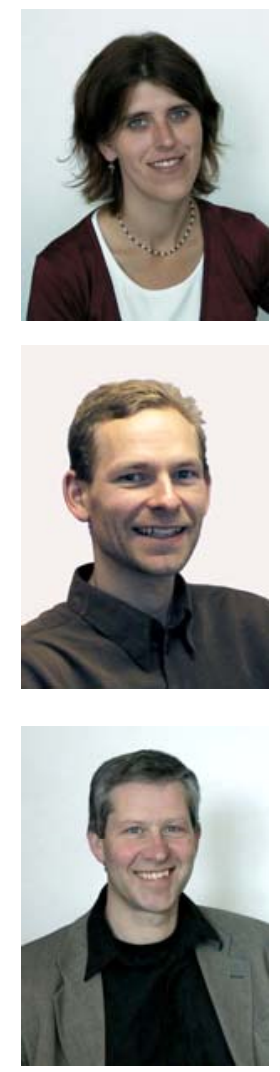

Forfatterne har arbejdet sammen om det e-leringsprodukt, der henvises til i artiklen (SWIM). Dette har fort til mange falles aktiviteter såsom afholdelse af og deltagelse i såvel danske som internationale seminarer og konferencer. Arbejdet har både i ånd og handling veret prceget af dynamiske og udviklende diskussioner om grundlagspcedagogiske udfordringer i det hyperkomplekse samfund, hvilket denne artikel også er et udtryk for. 
Det er en kendt sag, at pædagogik og samfundets form har fulgtes ad op gennem tiden. Gående fra løsningsbaseret læring over opgavebaseret til problembaseret læring - og som den sidste tendens - det man kan kalde behovsbaseret læring (Qvortrup 1998, 01 og 04).

For at kvalificere den forskningsbaserede undervisning i forhold til samfundets form, har forskningsbiblioteket også ændret karakter. Før oplysningstiden var klostre med biblioteker det sted, hvor munkene sad og skrev af. Bibliotekets ideal var at kopiere bøger med henblik på spredning af viden om Guds skaberværk - til de indviede.

Senere kom universiteter med tilhørende biblioteker. Her var idealet encyklopædiske samlinger forskere og studerende havde spørgsmålene - bøgerne havde svarene. Vi ser stadig spor af denne tradition.

Samfundets og dets produktionsapparats kompleksitet stiger imidlertid med industrialiseringen i en sådan grad, at det ikke mere altid er klart, hvad det er for et problem, man står med, når man konstaterer, at der er noget galt. Hermed bliver forskningsbiblioteket et omdrejningspunkt for læreprocessen, hvor biblioteksressourcer med nogen usikkerhed løbende må konsulteres. Det er en kendt sag, at moderne forsknings- og studieprocesser er kendetegnet ved, at der gennem hele processen stilles skarpere på problemet. Idealet er således, at forskningsbibliotekaren på opfordring af studerende eller forsker indgår konsulterende og vejledende i læreprocesser med informationsfaglig vejledning, en udvikling man i bibliotekssektoren har yndet at manifestere i læringsressourcecentre - LRC. Tendensen er her, at studerende og forskere selv skal bidrage med den nødvendige viden til at navigere i forskellige søgesystemer. Denne viden indgår ideelt set i synergi med den viden, bibliotekerne stiller til rådighed om hensigtsmæssig søgeadfærd. I slutningen af 90'erne var holdningen, at publikum ideelt set selv håndterede søgeprocessen; men det viste sig, at den særlige faglige disciplin - som bibliotekarer excellerer i - netop er en særlig faglighed, man ikke kan forvente at studerende - eller forskere - er specialister i.

Den problembaserede pædagogik er i sit udgangspunkt kendetegnet ved, at hverken problemet eller arbejdsformen er kendt. Fælles for de løsningsbaserede, opgavebaserede og problembaserede pædagogiske modeller er, at der er valgt en bestemt faglighed i udgangspunktet - altså tænkes der på konkrete uddannelser ${ }^{1}$. Den problembaserede pædagogiske model er imidlertid under pres af samfundets hyperkomplekse indretning - altså det grundvilkår at samfundets kompleksitet ikke kan reduceres entydigt, og vi er indstillet på dette i den måde vi er i samfundet på (Qvortrup, 1998). Man siger: Der findes flere sandheder om de samme fænomener. Der findes flere optikker på de samme fænomener - og i denne sammenhæng: Forskellige fagligheder kan anvendes på de samme behov.

Den nye pædagogiske tendens - som vi foreslår at kalde den behovsbaserede pædagogiske model - står i modsætning hertil ved, at fagligheden ud over problem og arbejdsform også er ukendt i udgangspunktet. Det skal derfor medreflekteres i læringsprocessen, hvilke fagligheder der skal vælges og kombineres i forhold til det behov, der adresseres i den studerendes eller forskerens omgivelser. Den behovsbaserede pædagogiske model betyder ikke, at man ikke skal arbejde problem-, opgave- og løsningsbaseret. Det betyder blot, at man i læreprocessen skal medreflektere kombinationen og prioriteringen af fagligheder, hvilket tilføjer endnu en dimension til den kom-

\footnotetext{
${ }^{1}$ I modsætning til den konventionelle og normative definition af problembaseret pædagogik, arbejdes der her med en systematisk definition. Derved gives der afkald på begrebets sproglige bredde til gengæld for en begrebsmæssig præcision. En præcision der er nødvendig i forhold til artiklens pointe omkring nye uddannelsesstrukturer."
} 
plekse brug og det usikre valg af søgestrategier i forhold til forskningsbibliotekets udbud af materialer.

Flerfaglighed er konsekvensen af den behovsbaseret pædagogiske model - et nødvendigt middel i læringsprocessen.

Denne artikel handler - med vinklen e-læring - om, hvordan Aalborg Universitetsbibliotek arbejder med at være en integreret del af læreprocesserne i universitetsuddannelserne.

Den virtuelle undervisningsform - uden fysisk tilstedeværelse - er et kendt fænomen, der alene stiller krav om e-læring - forstået som fleksibel netstøttet undervisning - herunder adgang til biblioteksressourcer. Dette gives i dag via biblioteksportaler som www.aub.aau.dk. Her er der ekstern adgang til store mængder elektronisk materiale i fuld tekst (databaser, artikler, bøger, opslagsværker etc.). Derfor er tid og sted ikke særlig vigtigt i forhold til at få fat i det materiale og den information, man som studerende eller forsker har brug for, og det passer godt til de præmisser, der stilles op for moderne netstøttet undervisning.

Hertil kommer forsøgsordninger med fælles virtuel vejledning - eksempelvis: Biblioteksvagten, faglig vejleder/studiets vejleder i fællesskab med bibliotekets vejleder, online adgang til digitaliseret kursusmateriale, bøger til døren og forskellige nye mellemformer med vekselvirkning af tilstedeværelses- og elektroniske tilbud.

Inden vi kommer til konkrete nye og anderledes e-læringsinitiativer på Aalborg Universitetsbibliotek, må vi lige en tur rundt om nye tværinstitutionelle uddannelses-strukturer, der illustrerer behovet for disse initiativer.

\section{Nye uddannelsesstrukturer}

I lyset af den behovsbaserede pædagogiske model, hvor forskellige fagligheder skal kombineres, synes det åbenbart, at læringsprocesser på tværs af faglige grænser skal understøttes. Vi giver her et par eksempler på uddannelsestilbud, der dels afspejler den behovsbaserede pædagogiske model, og dels synliggør behovet for nye fleksible og generiske biblioteksløsninger.

Efter- og videreuddannelsesaktiviteter (Master, Diplom og ikke-gradsgivende kurser) er ofte kendetegnet ved flerfaglighed, idet de studerende bidrager til uddannelsesaktiviteterne med forskellige faglige baggrunde. Sådanne aktiviteter er under pres for en mere fleksibel model - både hvad angår fysisk tilstedeværelse og tidspres. Livslang uddannelse betyder, at man uddanner sig parallelt med sit arbejdsliv, og hvis man samtidigt skal være tilstede på sin arbejdsplads og på studiet, må mindst den ene tilstedeværelse være virtuel. Uddannelsesstrukturen inden for efterog videreuddannelse er i dag kendetegnet ved et omfang svarende til et $1 / 2$-tids arbejde, og det er for mange umuligt at få til at gå tidsmæssigt op ved siden af et moderne privatliv og videnarbejde - et arbejde der ofte har et omfang på langt over 37 timer om ugen.

Derfor kommer der tilbud som ITEV ${ }^{2}$ - IT Efter og Videreuddannelse (www.itev.dk) i regi af ITvest, hvor studerende tilbydes IT-fagpakker af 15 ECTS point ${ }^{3}$ og herunder uddannelseselemen-

\footnotetext{
2 ITEV udbydes i regi af IT-vest samarbejdet, der er et samarbejde mellem Aalborg Universitet, Aarhus Universitet, Handelshøjskolen i Århus og Syddansk Universitet. Formålet med it-vest er at styrke udbuddet af erhvervsrettede IT-uddannelser i Vestdanmark samt fremme det flerfaglige samarbejde inden for IT (www.it.vest.dk).

${ }^{3}$ ECTS = European Credit Transfer and Accumulation System. 60 ECTS er et årsværk målt i studieindsats. En mastergrad udgør 60 ECTS - et årsværk.
} 
ter helt ned til en 1/12 IT-Master, der fleksibelt kan sættes sammen efter den studerendes udviklings- og erhvervsmæssige behov. Overordnet er ITEV struktureret i tre faglige specialiseringer: Softwarekonstruktion - Interaktionsdesign \& Multimedier - Organisation. Men den IT-Master studerende kan kombinere uddannelseselementer på tværs af specialiseringerne, og når studerende individuelt sætter uddannelser sammen, vil de studerende mødes fysisk og virtuelt på kryds og tværs af udbudte uddannelseselementer - ikke inden for samme 'uddannelse'. Fænomenet 'uddannelse' skal altså ses i den enkelte studerendes optik - institutionerne udbyder ikke en bestemt uddannelse med en bestemt faglighed, men en ramme for uddannelsesmuligheder hvor den studerende selv kan vælge og prioritere forskellige faglige perspektiver på sin uddannelse. Et andet fleksibelt og tværinstitutionelt tilbud er Master i Læreprocesser (MIL), der ganske som ITEV er delt op i mindre moduler; om end udbudet ikke er så stort - det er mindre generisk.

Det Danske Akademi for Digital, Interaktiv Underholdning (DADIU - www.dadiu.dk) er eksponent for en behovsbaseret pædagogisk model inden for dagstudierne - DADIU er også kendt som "Spiluddannelsen". Der deltager studerende fra 12 forskellige uddannelser og 8 forskellige institutioner over hele landet (Aalborg Universitet, Animationsværkstedet - CVU Midt-vest Viborg, Aarhus Universitet, Den Danske Filmskole, Danmarks Designskole, IT-Universitetet i København, Danmarks Tekniske Universitet og Københavns Universitet). Alle studerende i samarbejdet har et fælles pensum (15 ECTS), og heraf følger også referencer til fælles materialer. De studerende mødes fysisk på fællesproduktioner, hvor de bidrager med roller som projektleder, spil-instruktør, spil-designer, programmør, grafiker, animator, og lyd-designer. På fællesproduktionerne kreeres computerspil i teams, der afspejler computerspilsteams i erhvervslivet. Metodologien bag de enkelte kreationer er, at de deltagende studerende orienterer sig mod en fælles behovsoplevelse, der løbende justeres gennem projektet. De studerende forbereder sig endvidere på tværs af institutioner og fag inden de samles fysisk.

Pointen er her, at både inden for efter- og videreuddannelse og på dagstudierne er der nye uddannelsesaktiviteter, der ud over de studerendes fravær fra fysisk tilstedeværelse er kendetegnet ved nye uddannelsesstrukturer på tværs af fagligheder.

De nye strukturer, der opstår ved nye faglige kombinationer i uddannelsestilbudene, stiller endvidere krav til generiske biblioteksløsninger. Løsninger der passer ind i forskellige faglige kombinationer og samarbejdsformer - på tværs af uddannelser, institutioner og faglige traditioner.

Det er som nævnt en historisk kendsgerning at pædagogik og samfundets indretning følges ad og da samfundets hyperkomplekse indretning fordrer en behovsbaseret pædagogik, kan vi også forvente at en række af flerfaglige uddannelsestilbud på tværs institutioner vil skyde op - eksemplerne, der er nævnt her, er blot nogle af de første tilbud.

\section{Konkrete e-læringsinitiativer: SWIM og LOW}

På Aalborg Universitet har man en tradition for en problembaseret læringsmodel, hvorfor man på universitetsbiblioteket igennem flere år har arbejdet konkret med at understøtte læreprocesser hos den enkelte, i tråd med universitetets pædagogik igennem bibliotekets undervisningstilbud.

Kernen i denne undervisning har været SWIM - Streaming Webbased Information Modules ${ }^{4}$ (Rosenstand og Rosenstand 2004) [Rosenstand, Claus 04], der er en interaktiv video-film. Her

\footnotetext{
${ }^{4}$ SWIM: http://www.aub.aau.dk/portal/js_pane/forside/article/128. SWIM er tildelt Forskningsnettes innovationspris 2005: ”Det gyldne snit”: http://www.swiminfo.dk/Innovationsprisen.html.
} 
skal man deltage i en virtuel projektgruppe, som vælger mellem forskellige informationssøgestrategier i forskellige situationer ${ }^{5}$, der opstår undervejs i den interaktive video, der simulerer et projektforløb.

SWIM er velegnet til undervisning i informationssøgestrategier - ind til niveauet for en problembaseret pædagogik; men SWIM omfatter ikke det kulturelle aspekt omkring flerfaglige uddannelser, og omfatter dermed heller ikke en behovsbaseret pædagogisk model.

Den bagvedliggende informationssøgestrategi-metodologi i SWIM (SWIM-metodologien) har blandt andet vist sin styrke ved at blive konkret anvendt i UniEngelsk, der er en fleksibel masteruddannelse på Aalborg Universitet, som udbydes i moduler (www.uniengelsk.aau.dk). Her har man direkte integreret SWIM som en del af et metodekursus om problembaseret læring, projektkursus og informationssøgning - og der refereres i projektvejledningsprocessen til SWIMmetodologien. Dette lader sig kun gøre på grund af et tæt samarbejde mellem underviserne på UniEngelsk og Aalborg Universitetsbibliotek, hvor personerne bag undervisningen har et dybdegående kendskab til SWIM-metodologien.

Det er vores erfaring, at der mangler et dynamisk værktøj, der formidler SWIM-metodologien i de virtuelle læringsmiljøer for studerende og videnskabeligt personale, således at der med dette værktøj kan skabes en bedre forståelse for bibliotekets rolle i de eksisterende pædagogiske modeller.

Hertil kommer muligheden for, at videreudvikle SWIM-metodologien til også at omfatte en behovsbaseret pædagogiske model - værktøjet skal understøtte en medreflektering af det flerfaglige i læringsprocessen.

På baggrund af dette er Aalborg Universitetsbibliotek ved at udvikle et nyt værktøj: Learning Objects Web (LOW), til at facilitere og styre forholdet mellem skriveproces, informationssøgningsproces og læreproces. Tanken er, at LOW skal integreres fuldt ud i de virtuelle læringsmiljøer, der bruges i undervisningen. I skrivende stund er kreationen af LOW (arbejdstitel) netop begyndt, og Danmarks Elektroniske Fag- og Forskningsbiblioteker (www.deff.dk) støtter projektet.

Strukturen i SWIM-metodologien danner baggrund for strukturen i det nye værktøj. SWIM er en fase-orienteret model, hvor læring og informationssøgningsprocessen er to sider af samme sag. LOW bliver udviklet som en generisk komponent, der kan integreres i forskellige virtuelle læringsmiljøer. Værktøjet bliver et milepælsorienteret styringsværktøj, der anvendes via et webinterface. Idéen er, at der kan tilføjes og fjernes læringsobjekter, som passer til det enkelte studie, gruppe eller individ alt efter behov og engagement, og at disse læringsobjekter præsenteres for brugerne på det rette tidspunkt set i forhold til projektskrivningen. Dermed faciliteres en refleksionsproces omkring informationssøgningsprocessen som en del af læreprocessen.

Da LOW integreres i de virtuelle læringsmiljøer, hvor den studerende har sin dagligdag, vil værktøjet danne et bedre og bredere grundlag for den studerendes udvikling af informationskompetence.

Visionen for LOW projektet er at udvikle en ny og mere åben version af SWIM således, at elæringssystemet bliver mere fleksibelt og generisk (nedbrudt i læringsobjekter), som eksempelvis

\footnotetext{
${ }^{5}$ Dette er gjort ved at krydstabulere Carol C. Kuhlthau informationssøgefaser (Kuhlthau 2004) med Lars Qvortrups læringssystematik (Qvortrup, Lars 1998, 01 og 04). Læs mere i (Rosenstand og Rosenstand 2004)
} 
kan integreres via web-services i portaler eller linkes til fra kursuspakker i andre virtuelle læringsmiljøer. Vi håber hermed at kunne tilbyde større åbenhed og fleksibilitet og give mere generiske anvendelsesmuligheder for e-læringssystemets elementer.

SWIM og videreudviklingen LOW matcher således nye uddannelsesstrukturer, der igen matcher samfundets hyperkomplekse beskaffenhed. Dermed tages de første skridt i retning af også at integrere forskningsbiblioteket i nye læreprocesser, der bygger på en behovsbaseret pædagogisk model.

\section{Litteratur}

Kuhlthau, Carol C.: Seeking meaning: a process approach to library and information services, London: Greenwood Press, 2004

Qvortrup, Lars: Det vidende samfund: Mysteriet om viden, læring og dannelse, København: Unge Pædagoger, 2004

Qvortrup, Lars: Det lærende samfund: Hyperkompleksitet og viden, København: Gyldendal, 2001.

Qvortrup, Lars: Det hyperkomplekse samfund: 14 fortællinger om informationssamfundet, Gyldendal, 1998

Rosenstand, Claus og Rosenstand, Maj: SWIM. In: Biblioteksårbog 2003. Eds. Anna Rasch, Annette Schneider, Lissa Shin \& Jens Thorhauge. Kønbenhavn: Bibliotekstyrelsen, 2004.

Rosenstand, Claus: Pedagogical Forms in Simulative E-Learning Systems. In: $12^{\text {th }}$ Nordic I \& D - Knowledge and Change - Proceedings of the $12^{\text {th }}$ Nordic Conference for Information and Documentation. Ed. Marianne Hummelshøj. Aalborg: Royal School of Library and Information Science, 2004. 